\title{
Raising the Tourism Industry as an Economic Driver Post COVID -19
}

\author{
Awliya Afwa ${ }^{1 *}$, Nico D. Djajasinga ${ }^{2}$, Acai Sudirman ${ }^{3}$, Avid Leonardo Sari ${ }^{4}$, Adlhan \\ Nury M. Adnan ${ }^{5}$
}

${ }^{1}$ Universitas Islam Riau, Indonesia

${ }^{2}$ Politeknik Transportasi Darat Indonesia, STTD

${ }^{3}$ Sekolah Tinggi Ilmu Ekonomi Sultan Agung, Indonesia

${ }^{4}$ UIN Sunan Gunung Djati, Bandung, Indonesia

${ }^{5}$ GoAcademica Result and Publishing, Indonesia

Corresponding Email: awliyaafwa@echo.uir.ac.id

\begin{abstract}
The COVID-19 outbreak spread throughout the world and developed into a non-natural disaster. This pandemic has created crises in various fields, including in the tourism sector. The tourism sector is one of the sectors hardest hit by this disaster because almost every country in the world prohibits its citizens from traveling and prohibits all tourist objects from operating to prevent crowds and crowds that are the main cause of the rapid spread of this dangerous virus. Those who work in the travel, leisure, catering, cooking, and recreation sectors ask what if there is no economy, workplace, or stable revenue stream tomorrow. Tourism as the most humanly focused and labor-intensive sector represents the future in the collapse of the post-Apocalyptic society of millions of hard-working people. The report was then carried out so that after the COVID-19 epidemic, an analysis of the tourism industry was completed. The presentation of research-related data uses qualitative methods.
\end{abstract}

Keywords: Tourism, Global, COVID-19, MERS

\section{INTRODUCTION}

We are in a serious global pandemic, and fear is one part of our everyday lives, whether good or bad (Sulistiani \& Kaslam, 2020). This study aims to address some questions that might be on most people's minds; people who work in the tourism and hospitality industries; people who ask what it would look like tomorrow when no business, employment, or stable source of income is available. As the most human and labor-intensive sector, tourism is the future of millions of hard laborers who might feel left to themselves in the collapsed post-apocalyptic world (Sugihamretha, 2020).

SARS COV-2, or $2019 \mathrm{nCoV}$, or COVID-19, is derived from the respiratory system (airway systems like the mouth, nose, nose, neck, and lungs) of the mammals' coronavirus family and which induces mild-to-severa infections in mammals (Stadnytskyi et al, 2020). Coronavirus is in the family of Coronaviridae and the order Nidovirales of the Orthocoronavirinae. This viruses are named after their viral particles like the crown (Jaiswal \& Saxena,
2020). Over the last two decades, there have been two other family members outbreaks including the 2002 Severe Acute Coronavirus Respiratory Syndrome (SARS-CoV), which began in China and developed into a 2003 pandemic, and the 2010 Middle East Respiratory Syndrome (MERS-CoV) (Keil et al., 2016). MERS has contaminated 2,494 individuals in the last eight years (as of November 2019) and killed 858 people, mainly Saudi Arabia. 8,098 people have been contaminated with the SARS pandemic and in a short time 774 have been killed worldwide. Though less deadly than MERS, the SARS's large geographical range costs the world economy between US\$ 30 and US\$ 100 billion, whilst the mortality rate is 9.6 percent, relative to MERS' $34.4 \%$ even if they are less deadly (1-4\% so far) than SARS (Mubarak et al., 2019).

The widespread use of COVID-19 has been shown. We also failed to control this pandemic and the greatest historical containment attempts and the alert responses from most countries around the world. COVID-19 is more infectious and less contagious than SARS and Ebola than bird flu A (H7N9); (Marzuki et 
al., 2020). Global policymakers need to enforce lockdowns because of the high rate of new coronavirus spread (SARS-CoV-2). 2020). 2020).

Of all markets and businesses around the world, there were economic pandemic shocks. Some companies have seen unparalleled failures due to travel constraints and social distance, finding it extraordinarily difficult to endure this pandemic while adapting to new media and continuing their survival battle (Hanoatubun, 2020). Tourism is a sector that is unable to thrive without tourist mobility. Any hints of the catastrophe that COVID-19 could cause the touristic world to fall by $22 \%$ in the number of visitors in the first quarter of 2020 (as opposed to the same quarter 2019), and the possibility of $60-80 \%$ declines during 2020 (compared to 2019) (WTTC, 2020). Tourism is one of the highest fields of work. Such a downturn in the industry could endanger millions of jobs, threatening to reverse progress on sustainable development objectives (WTTC, 2020).

The World Travel and Tourism Board (WTTC) study report recently lists up to 75 million employees immediately at job risk from COVID-19. Research shows a possible deficit of up to US \$2.1 trillion for Travel Tourism's GDP 2020. The WTTC reports that the coronavirus pandemic has caused an enormous loss of an estimated one million workers every morning in the travel tourism market. In the Chinese Guangdong Province in 2002, Pine and McKercher (2004) investigated the effects of the SARS epidemic. Their findings demonstrate the negative, meaningful and important effects.

The time after recovery depends for important events on the extent of hysteresis and institutional performance. Kuo et al. (2008) found that tourism demand had a different effect on the disease crisis. Their SARS (2001-2004) study and avian influenza spread (2002-2006) showed that the effects of SARS on tourism demand in China, Hong Kong, Singapore, and Taiwan were important. However, despite the high mortality rate, the outbreak of bird flu did not negatively affect tourism demand in Asia. In previous research on the pandemic effects, however, recent patterns and characteristic features of COVID-19 must be taken into account. While the incoming tourism arrivals rebound in the previously common (SARS, 2002; H1N1, 2009), once the pandemic warning is lifted, COVID-19 will not occur. New scientific models of pandemic effects must be taken into account. The SARS affects Asian stock market integrations (Hindayani, 2020) and supports, to a small degree, the hygienic measures, but the COVID19 pandemic seems to need tougher measures. In the battle against COVID-19, information and communication technologies (ICT) will play a major role (He et al., 2021).

As Baum et al. (2020) showed, it is very important to investigate hospitality and tourism in the light of a pandemic. Researchers are beginning to concentrate on this area, but little work has been done to date. No more than 45 results, which research the effect of COVID-19 on the tourism industry, were provided by search queries on the science Web database. These experiments have also been found to be omnipresent and present-focused research challenges to the field. Such discrepancies in research do not greatly enrich expertise and are mainly beneficial to politicians and clinicians.

WHO proposes an early analysis to provide lawmakers with timely information for emergency response. Given the possibility of a pandemic of COVID-19, it is strongly advisable that the current literature be examined quickly. Such a report will not only consolidate the conclusions of current surveys but also provide prospective researchers input and guidance on exact problems facing the industry. The above topic motivates us to study the problems that the international tourism industry is facing after COVID-19.

\section{METHOD}

This study is a scientific thought product using observational approaches such as collecting and analyzing evidence and information in the form of records, journals, libraries, and other sources relevant to this research through secondary data inspection and interpretation. Descriptively, the findings were analyzed. A qualitative approach to research is a research and understanding process centered on methods that examine social and human problems. In this analysis, a complicated picture is developed, words are examined, the respondents' insights are reported in-depth, and the situation is studied Qualitative science is undertaken in natural environments and is a genuine innovation (Somantri, 2005). The analyst is the central tool of qualitative analysis. Researchers must also have a broad analytical understanding and intuition to pose questions, interpret the subject and construct the object to explain it. This research focuses on the significance and is linked to beliefs (Gunawan, 2013).

\section{RESULT AND DISCUSSION}

Tourism is a dynamic multiplex network structure. This ensures that millions of components communicate in a global network in different layers 
with local networks. Besides, tourism is an open system that exchanges material, energy, and environmental information. Around the same time, the tourism system brings many other processes such as the national and local economic and health systems in line with this very complicated one. The dynamic structure of the tourism environment results in some types of hub and speaker behaviors (Azzahra et al., 2018). In other words, we have many main players linked to several other components of the device on each layer of the network. Many components, on the other hand, are only connected to some neighbors. Structurally, in moments of accidental disaster, this mixture and this action lead to a stable and durable structure. The logic is simple; if one of these components fails at any time, they are more likely to be spoken (small local pubs, for example) than hubs (for example, large airlines), as hubs are fewer and there are more ramps. But during a targeted attack (for example, a terrorist attack), this mechanism is vulnerable, as the complete network will fail if many centers are removed (Patria, 2014)

At this point, there is no chance of discussing the deliberate assault situation. Conspiracy theorists can still be unsure, but COVID-19 RNA genetic analysis (similar to our DNA but in viruses) does not support the virus's root of armament and bioweapons. Once the research is correct, intentional attacks would not exist in the tourism system's durability analysis. Therefore, it may be said we may not have to concern ourselves with the effects on tourism of COVID-19 because tourism is immune to random failures. Although that assertion is not entirely false, I should stress that the impact of COVID-19 on tourism largely depends on the magnitude of the problem, the duration of exposure, and other tourist programs' circumstances. I need to consider the effect on the tourism system of many crises (particularly health problems and outbreaks) before clarifying what the new tourism system will do and how it will come into being.

In general, the health problem has a much lower slip curve in terms of depth of damage and recovery time than violence, environmental and political disasters. This means that the recovery period in tourism will not dramatically improve, even with a decline of over 30 percent of monthly visitors due to the health crisis. The time to a health disaster destination is between 12 and 34 months based on available evidence. On average, this means that a health crisis is normally about 22 months out, marginally less than natural disasters and global instability but slightly larger than incidents such as crime and oil spills. The positive thing is that the standard deviation from health emergencies is far less than natural and political instability, which means the average time for health catastrophe incidents is about the same (Hall, 2010)

The recovery time is also a case-based one Ebola is considered one of the most devastative effects on tourism at the regional level, for example, among western African countries. In Ebola, the foreign arrivals to Sierra Leone remain more than $50 \%$ below the rate before the epidemic 35 months after the outbreak. The rate of return to normal has to do with the destination and disaster health. The destination growth level, the crisis management mechanism, sustainability, preparation and readiness levels, and the future reserves of the products/resources needed are important in the destination assets. Any critical factors that affect return destination rates are the severity of a health disaster, the nature of the illness, and our disease responses, including the depth of the virus attacks, the rates of hospitalization, the spread, the death rates, the target population, Resistance to viruses, the incubation time and Viral care and vaccination. A very diverse sample of different possibilities appears as we mix a health catastrophe's goals and properties. Any destination, therefore, has its history of crisis management, and the behavior of the demand curve can differ from state to state. In Ebola, for example, the sudden decrease lasted approximately four quarters, and the number of visitors increased progressively (Maphanga \& Henama, 2019).

In 2015 Zika was in Brazil because of sinusoidal trends, with both increasing and declining numbers of visitors, the seasonal trend was retained (Gallivan, 2019). Seasonal demand was eradicated for 2001 in British foot and mouth disease, which stops tourist development, which remains at its level for two years before the outbreak (Lovelock et al., 2018). For SARS in Hong Kong, tourism demand decreased sharply (two quarters) for a short period, followed by sudden growth for one quarter that brought back normal demand (before the incident). In the last two years, demand then steadily grew. Finally, the region contributed to the effect of the health crisis on and stabilization of the tourism system. Usually, the areas in which the epidemic began were affected hardest. In the case of SARS, Asia and the Pacific have seen a decline in the number of visitors by 9 percent, while in the Middle East, the number of visitors has increased by 3.4 percent. The world average tourist rate has decreased by 1.7 percent, down from 703 to 691 million, resulting in a corresponding decrease in the income for tourism. However, one year after the 2004 pandemic, tourism rose by $27.9 \%$ in Asia-Pacific and 
$10.7 \%$ in global tourism, from 690 million tourists to 763 million. Also, in the more extreme case of H2N2 in 1957, the number of tourists worldwide quickly recovered from around 50 million in 1955 to more than 112 million in 1965, by 126 percent; (Kuo et al., 2008).

For COVID-19, an average 1 percent-3 percent decrease in world visitor volume was observed in the preliminary assessments and forecasts. The horror is projected to increase the number of arrivals by at least $3 \%-6 \%$ (or up to $30 \%$ in the worst scenario), suggesting a reduction of sales of at least $\$ 80$ billion. This is in comparison to the large losses in the transport sector, where only one share (i.e., airlines) in the first few months lost over $\$ 100$ billion (equal to the economic effect of SARS as a whole) (WTTC, 2020). Unlike past pandemics, COVID-19 is even more aggressive than ever before in the tourism system. Not only have they been attacked (e.g., every day SMEs go bankrupt), but hubs have also been placed under enormous strain (e.g., the cruise ship industry, the airline industry, hotel chains, urban tourism, theme parks, and casinos). There is considerable fear that COVID-19 is simultaneously targeting hubs and speeches on a large and influential surge. The machine collapses if the crash on the hub lasts long enough. Other institutions connected with the tourism sector are already on the verge of selfregulation, including the economic and health systems; failure would lead me to expect too many other systems, including tourism, to fail. Many of these events worry us greatly and take us to the brink of anarchy. Complex networks are nevertheless no stranger to confusion on edge. The machine then uses its free capability to spread tension in its balance part to the troubling part (region).

Although COVID-19 damages the northern hemisphere, the southern hemisphere is not as damaged. The effect would be spread over time, with a time latency element as a buffer to prevent the machine from crashing. If we look at previous history, it seems like tourism will be in order in one or two years from the point of view of the entire system after the conclusion of the COVID-19 pandemic. The previous history suggests that sometime after the recession concluded, the structure stabilized strongly. Regardless of their nature, complex structures are more resilient, as they employ a mixture of two methods to avoid change and respond to change by default. The mechanism prevents and retains equilibrium as long as services are not overused and modules are not overwhelmed, thereby avoiding shifting circumstances.
However, the mechanism causes trouble to pass unhindered as the fault forces surpass the system's Resistance and modules are overwhelmed. Indeed, the device attempts to make the transition phase easier by using distraction and anxiety entropy. The machine will suffer a soft failure to prevent catastrophic failure due to this shift in strategy. The first technique is analogous to a dam for a flooded environment. The second is constructing a comprehensive network for storm drains (i.e., adjusting to change) to prevent flooding. But it is not without costs to move from one technique to another. The machine shows a series of responses depending on the degree and severity of the disturbance. The process change is one final and dramatic procedure for preserving the consistency of the structure. The machine searches for a new equilibrium after the transformation. After the transition. Transitions in phase are like a chunk of ice melting.

The processes are the same, but we are concerned with a water status with several distinct and identical characteristics to the previous state instead of being in strong status (e.g., ice). We seem to be undergoing a transformation process with COVID-19, which would transform the market. Any of these amendments take the form of a corporate model. For instance, the airline industry started to distinguish between airlines after $9 / 11$, and the model of low-cost airline business displaced much of the conventional airline business model. Airline companies have been bankrupt by several large airlines. The results of COVID-19 may be predicted to result in similar systemic and functional improvements in tourism. Deglobalization is another important change to the tourism scheme.

Although globalization has shown high efficiency in many ways, regional sovereignty will likely grow with local institutions' empowerment. Globalization has a threshold, and the best benefit for its progress is paramount. Any of our networks have been vulnerable to multiple catastrophes due to unnecessary globalization. Not a day without the reports of machine defeats due to excessive globalization. It is now time for a certain location (if we persist). There will be a day tomorrow without new COVID-19 incidents worldwide. It's going to be very different every day. We will no longer see our beloved neighborhood café as we return from selfimposed isolation and quarantine. There may not have been a bed and breakfast around the corner.

We start looking at brand new airlines, but there we are, the infrastructure is there, and the turnaround starts. The tourism and travel industry's effect on the spread of COVID-19 cannot be denied to anyone. We 
are part of the challenge and part of the solution (postCOVID-19). But many young people will work in this industry; in remote towns of West Africa, tourism will also inspire many women; in Europe, tourism continues to be a beating center, and poverty alleviation is one of our top agendas. Complex networks are generally very well synced with tourism. It would soon be compatible with other schemes of legal, economic, and environmental policy. When the nightmare is done, we are in a modern world of new standards and new standards and norms. When they learn through feedback loops, complex systems are flexible. The system's self-organization ability would make them even harder to defeat new animals. The question is, are we to learn from our lessons? They will learn their lessons.

The next epidemic is about to occur. A new virus or natural catastrophe will grab our eye much earlier rather than later, but are we prepared? Some countries such as Hong Kong and Singapore, which SARS has worst hit to date, are doing better with COVID-19. (Note: however, it is necessary to remember the population of those nations. Compared with major countries such as China, India, the United States, and Indonesia, Hong Kong and Singapore have populations of less than 15 million in common.). The response to this question is unclear, but the fact that nature has always found ways of restoring equilibrium between the processes - whether with 98 percent documented extinction, plant, and fauna, by meteorites, or by viruses - is evident and confirmed over millions of years. Our responsibility is to synchronize our processes with nature and to find ways of maintaining harmony.

\section{CONCLUSION}

A multidimensional tragedy, the COVID-19 pandemic has devastated all life facets, and the tourist industry included. This business and its derivatives linked to tourism have utterly paralyzed the presence of a lockout program in virtually all countries worldwide (hub \& spoke). This differs greatly from previous outbreak cases, which typically target the spoken sector (such as the case of MERS, SARS, Zika, Ebola, etc.). There is considerable fear that COVID-19 is simultaneously targeting hubs and speeches on a large and influential surge. The machine collapses if the crash on the hub lasts long enough. Other institutions connected with the tourism sector are already on the verge of self-regulation, including the economic and health systems; failure would lead me to expect too many other systems, including tourism, to fail. However, after the impact of recent pandemics, tourism will continue to increase and boost the world's economy once again. When the nightmare has ended, the tourism industry will flourish and prosper again in a modern era of new regulations and norms.

\section{REFERENCES}

[1] Azzahra, H. J., Astuti, W., \& Rini, E. F. (2018). Komponen Keterpaduan Objek Wisata di Kawasan City Walk Slamet Riyadi Ditinjau dari Sistem Pariwisata. Region: Jurnal Pembangunan Wilayah dan Perencanaan Partisipatif, 13(1), 20-36.

[2] Baum, T., \& Hai, N. T. T. (2020). Hospitality, Tourism, Human Rights and the Impact of COVID-19. International Journal of Contemporary Hospitality Management.

[3] Gallivan, M., Oppenheim, B., \& Madhav, N. K. (2019). Using Social Media to Estimate Zika's Impact on Tourism: Babymoon, 20142017. PloS one, 14(2), e0212507.

[4] Gunawan, I. (2013). Metode Penelitian Kualitatif. Jakarta: Bumi Aksara.

[5] Hall, C. M. (2010). Crisis events in tourism: subjects of crisis in tourism. Current Issues in Tourism, 13(5), 401-417.

[6] Hanoatubun, S. (2020). Dampak Covid-19 terhadap Prekonomian Indonesia. EduPsyCouns: Journal of Education, Psychology and Counseling, 2(1), 146-153.

[7] He, W., Zhang, Z. J., \& Li, W. (2021). Information Technology Solutions, Challenges, and Suggestions for Tackling the COVID-19 Pandemic. International Journal of Information Management, 57, 102287.

[8] Hindayani, N. (2020). Analisis Reaksi Pasar Saham atas Peristiwa Covid-19 di Indonesia. Jurnal Ilmiah MEA (Manajemen, Ekonomi, \& Akuntansi), 4(3), 1645-1661.

[9] Jaiswal, N. K., \& Saxena, S. K. (2020). Classical Coronaviruses. In Coronavirus Disease 2019 (COVID-19) (pp. 141-150). Springer, Singapore.

[10] Keil, S. D., Bowen, R., \& Marschner, S. (2016). Inactivation of Middle East Respiratory Syndrome Coronavirus (MERS-C O V) in Plasma Products Using a Riboflavin-Based and Ultraviolet Light-Based Photochemical Treatment. Transfusion, 56(12), 2948-2952.

[11] Kuo, H. I., Chen, C. C., Tseng, W. C., Ju, L. F., \& Huang, B. W. (2008). Assessing impacts of SARS and Avian Flu on international tourism 
demand to Asia. Tourism Management, 29(5), 917-928.

[12] Lovelock, B., Lovelock, K., \& Lyons, K. (2018). The Impact of Outbound Medical (Dental) Tourism on the Generating Region: New Zealand Dental Professionals' Perspectives. Tourism Management, 67, 399410.

[13] Maphanga, P. M., \& Henama, U. S. (2019). The Tourism Impact of Ebola in Africa: Lessons on Crisis Management. African Journal of Hospitality, Tourism and Leisure, 8(3), 1-13.

[14] Marzuki, I., Bachtiar, E., Zuhriyatun, F., Purba, A. M. V., Kurniasih, H., Purba, D. H., ... \& Airlangga, E. (2021). COVID-19: Seribu Satu Wajah. Yayasan Kita Menulis.

[15] Patria, T. A. (2014). Tinjauan Sistem dan Elemen Pariwisata di Kabupaten Badung, Bali, melalui Sistem Pariwisata Leiper. Binus Business Review, 5(1), 66-79.

[16] Pine, R., \& McKercher, B. (2004). The impact of SARS on Hong Kong's tourism industry. International Journal of Contemporary Hospitality Management.

[17] Somantri, G. R. (2005). Memahami Metode Kualitatif. Makara Hubs-Asia, 9(2), 57-65.

[18] Stadnytskyi, V., Bax, C. E., Bax, A., \& Anfinrud, P. (2020). The Airborne Lifetime of Small Speech Droplets and Their Potential Importance in SARS-Cov-2 Transmission. Proceedings of the National Academy of Sciences, 117(22), 11875-11877.

[19] Sugihamretha, I. D. G. (2020). Respon Kebijakan: Mitigasi Dampak Wabah Covid-19 Pada Sektor Pariwisata. Jurnal Perencanaan Pembangunan: The Indonesian Journal of Development Planning, 4(2), 191-206.

[20] Sulistiani, K., \& Kaslam, K. (2020). Kebijakan Jogo Tonggo Pemerintah Provinsi Jawa Tengah dalam Penanganan Pandemi Covid-19. Vox Populi, 3(1), 31-43.

[21] World Travels and Tourism Council (2020) Impact of Pandemic on Travel and Tourism. Retrieved from: https://www.wttc.org/priorities/crisispreparedness/pandemics/ [Access on January 14, 2022]

[22] Yunus, N. R., \& Rezki, A. (2020). Kebijakan Pemberlakuan Lock Down Sebagai Antisipasi Penyebaran Corona Virus Covid-19. Salam: Jurnal Sosial dan Budaya Syar-i,7(3), 227238. 